\title{
Characteristics and sources of polycyclic aromatic hydrocarbons in impervious surface run-off in an urban area in Shanghai, China
}

\author{
Juan $\mathrm{HOU}^{\dagger}$, Lu BIAN, Tian LI ${ }^{\dagger \dagger}$ \\ (State Key Laboratory of Pollution Control and Resource Reuse, Tongji University, Shanghai 200092, China) \\ †E-mail: houjuan@tongji.edu.cn; tianli@tongji.edu.cn \\ Received May 30, 2013; Revision accepted Sept. 3, 2013; Crosschecked Sept. 12, 2013
}

\begin{abstract}
Rainwater and run-off from three kinds of impervious surface in the Shanghai urban area, China were sampled. Polycyclic aromatic hydrocarbons (PAHs) were measured in the samples, and their sources were assessed. The mean sum of the 16 PAH concentrations measured in rainwater and run-offs from ceramic tiles, asphalt roofs, and asphalt roads were 873, 1404, 1743, and $4023 \mathrm{ng} / \mathrm{L}$, respectively. The PAH concentrations found in this study were moderate compared to PAH concentrations found in run-offs in other studies. The main PAH components in the rainwater, roof run-off, and asphalt road run-off samples were 3-ring PAHs, 3-4-ring PAHs, and 4-6-ring PAHs, respectively. Source apportionment results indicated that combustion (47.4\%-55.5\%) and vehicular emissions $(30.5 \%-33.0 \%)$ were the major contributors to PAHs in roof run-off. Vehicular emissions were the most significant contributors to asphalt road run-off (47.2\%), followed by combustion (23.5\%), and petroleum (16.3\%). Vehicular emissions and coal and natural gas combustion are therefore the most significant sources of PAHs in run-off from impervious surfaces in the Shanghai urban area.
\end{abstract}

Key words: Polycyclic aromatic hydrocarbons (PAHs), Impervious surface, Run-off pollution, Source apportionment doi: $10.1631 /$ jzus.A1300155

Document code: A

CLC number: X5

\section{Introduction}

Many surfaces in urban areas are impervious, including roads (Krein and Schorer, 2000) and the roofs of buildings (Chang et al., 2004). Stormwater run-off from urban impervious surfaces can contain significant quantities of pollutants, including nutrients, heavy metals, and polycyclic aromatic hydrocarbons (PAHs) (Ngabe et al., 2000; Chang et al., 2004; Lau et al., 2009). PAHs are of great concern because of their potential toxicities, carcinogenicities, and teratogenicities. PAHs are organic compounds that contain two or more fused benzene rings and have mainly anthropogenic sources, including the

\footnotetext{
Corredsponding author

* Project supported by the National Key Technology R\&D Program of China (No. 2010BAK69B16-1), and the Shanghai Commission of Science and Technology (No. 10dz1200402), China

(C) Zhejiang University and Springer-Verlag Berlin Heidelberg 2013
}

incomplete combustion of organic matter (such as coal, wood, oil, and petroleum), vehicle exhausts, road aging, and oil spills (Valle et al., 2007). PAHs are ubiquitous in urban stormwater run-off, so monitoring the PAH contamination in the run-off and apportioning the PAH sources are critical for assessing and protecting aquatic ecosystems.

PAH pollution in stormwater run-off has been studied in a number of places and relatively high PAH concentrations have been found (Ngabe et al., 2000; Grynkiewicz et al., 2002; Lau et al., 2009; Mitsova et al., 2011; Bartlett et al., 2012). However, PAH characteristics and sources vary between different urban areas, making it necessary to study PAH pollution specifically in stormwater run-off in Shanghai.

Shanghai is located in the Yangtze River Delta in eastern China, and is one of the largest cities in China, with a total population of over 23 million and an area of $6340 \mathrm{~km}^{2}$. Shanghai has been troubled by serious environmental problems because of its rapid 
urbanization. Several recent studies have shown that various environmental media, such as soils, sediments, and wet deposition, in the Shanghai region are severely contaminated with PAHs (Liu et al., 2008; Liang et al., 2011; Yan et al., 2012). However, little research has been conducted on PAHs in impervious surface run-off. The objectives of this work were (1) to measure PAH concentrations in impervious surface run-off in the Shanghai urban area, (2) to compare the PAH compositions of different surface run-offs, and (3) to determine the primary PAH sources and their relative contributions in the study area. In this work, for the first time PAHs in rainwater, roof run-off and road run-off samples were measured simultaneously in Shanghai. The results of this study provide information on the characteristics and sources of PAHs in impervious surface run-off in the Shanghai urban area, which is important for protecting water resources and human health in that region.

\section{Materials and methods}

\subsection{Sampling site}

A mixed residential and commercial area around Tongji University was selected as the study area. Samples were collected from three impervious surfaces, and rainwater samples were collected on the rooftop of the Shengtai building at Tongji University. The sites, which are described in Table 1 and shown in Fig. 1, were less than $450 \mathrm{~m}$ from each other, and their environmental situations were considered to be comparable.

\subsection{Sample collection and preparation}

Run-off samples were collected manually at each site during each storm event. The samples were taken from a road gully and roof downspouts. When run-offs were generated, samples were collected every 5 min during the first $0.5 \mathrm{~h}$ of the storm event, and then every $10 \mathrm{~min}$ until the run-off ended.
Rainwater samples were collected in sampling basins and a rain gauge was used to measure the amount of rain at the sampling site. Seven rainfall events, between July and September, 2012, were monitored; the rainfall at the events ranged from 1.6 to $81.3 \mathrm{~mm}$.

The samples were transported to the laboratory immediately after collection. A flow-weighted composite sample for each sample site was prepared, so that the mean concentration for each pollution event could be obtained (Kafi et al., 2008; Diblasi et al., 2009). It was not possible to measure the run-off flow at every sample site because of experimental restrictions, so the cumulative rainfall weight was used instead of the run-off flow weight; we consider that is appropriate because of the small catchment areas and the short measurement times. The samples were stored below $4{ }^{\circ} \mathrm{C}$ and analyzed for PAHs within $48 \mathrm{~h}$ of collection.

\subsection{PAH extraction and analysis}

The procedure for the extraction and analysis of PAHs in rainwater and run-off samples is briefly described in Fig. 2. The samples were liquid-liquid

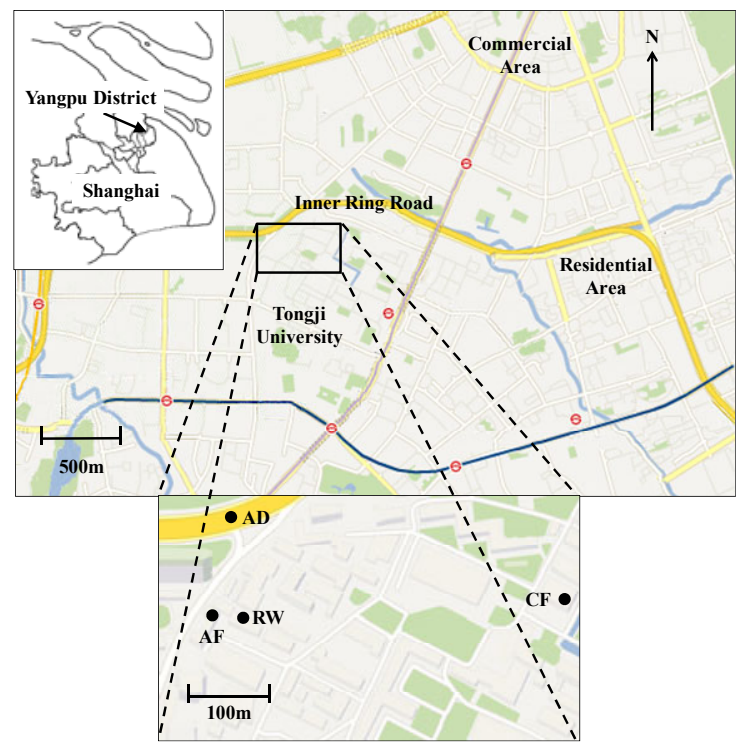

Fig. 1 Sample location map

Table 1 Characteristics of the sampling sites

\begin{tabular}{lllc}
\hline \multicolumn{1}{c}{ Description } & \multicolumn{1}{c}{ Sampling site } & \multicolumn{1}{c}{ Location } & Catchment area $\left(\mathrm{m}^{2}\right)$ \\
\hline Ceramic tile roof (CF) & Haiyang building & Tongji University & 120 \\
Asphalt roof (AF) & Engineering center & Tongji University & 85 \\
Asphalt road (AD) & Inner ring road & North Zhongshan 2nd road & 300 \\
Rainwater (RW) & Shengtai building & Tongji University & - \\
\hline
\end{tabular}


extracted then analyzed by high performance liquid chromatography (HPLC), based on the method HJ478-2009. $500 \mathrm{ml}$ of samples were transferred to a $500 \mathrm{ml}$ separatory funnel for liquid-liquid extraction. Each sample was extracted three times and the organic phases were combined in a $250 \mathrm{ml}$ roundbottomed flask, dried with anhydrous sodium sulfate, and concentrated to $1 \mathrm{ml}$ using a rotary evaporator. The concentrated extract was cleaned up on a $1 \mathrm{~g}$ silica gel column, which had been washed with $4 \mathrm{ml}$ of a mixture of hexane and dichloromethane $(1: 1$, in volume) then $10 \mathrm{ml}$ hexane, and eluted with $10 \mathrm{ml}$ of a mixture of hexane and dichloromethane $(1: 1$, in volume). The cleaned extract was concentrated to 1 $\mathrm{ml}$, added to $3 \mathrm{ml}$ acetonitrile, and finally concentrated to $0.5 \mathrm{ml}$.

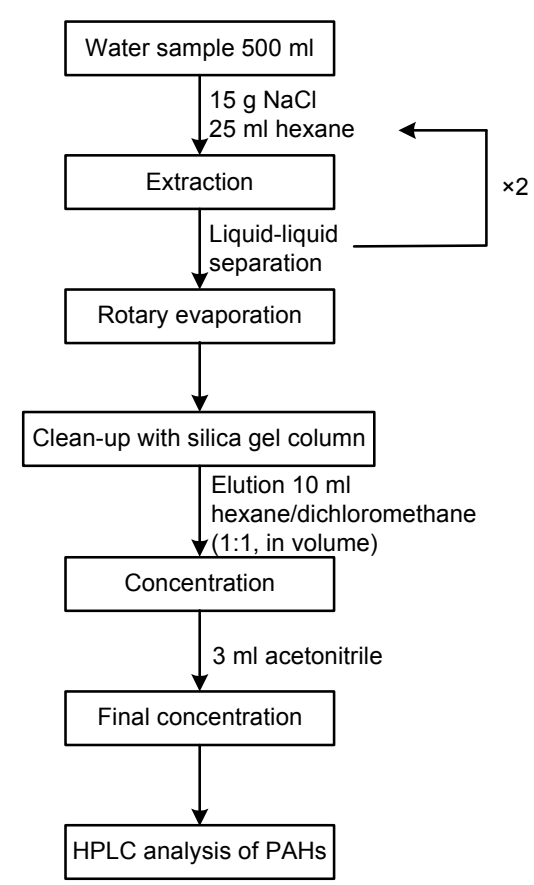

Fig. 2 Scheme of analytical procedure

The samples were analyzed by HPLC (LC-20A, Shimadzu, Kyoto, Japan) with a photodiode array detector (SPD-M20A) and an Inertsil ODS-P $\mathrm{C}_{18}$ column (4.6 mm $\times 250 \mathrm{~mm}, 5 \mu \mathrm{m}$ particles; GL Sciences, Torrance, CA, USA). A gradient elution program was used, with acetonitrile and deionized water mobile phases. A flow rate of $1.2 \mathrm{ml} / \mathrm{min}$ was maintained at a temperature of $35^{\circ} \mathrm{C}$, and the equilibration time was $30 \mathrm{~min}$. The elution profile had three steps: 0-15 min with $55 \%$ acetonitrile in deionized water,
$55 \%-100 \%$ acetonitrile linear gradient over $30 \mathrm{~min}$, then a constant $100 \%$ acetonitrile for $15 \mathrm{~min}$.

A series of calibration standard solutions, between 0.1 and $10 \mu \mathrm{g} / \mathrm{ml}$, were used. Sixteen PAHs that have been classified as priority control pollutants by the US Environmental Protection Agency were analyzed. These were naphthalene $(\mathrm{NaP})$, acenapthylene (AcNy), fluorene (FL), acenaphthene (AcNe), phenanthrene $(\mathrm{PhA})$, anthracene (An), fluoranthene (FlA), pyrene (Py), benzo $[a]$ anthracene (BaA), chrysene (Chy), benzo $[b]$ fluoranthene $(\mathrm{BaF})$, benzo $[k]$ fluoranthene $(\mathrm{BkF})$, benzo $[a]$ pyrene $(\mathrm{BaP})$, dibenzo $[a, h]$ anthracene (DBahA), indeno [1,2,3-cd] pyrene (IP), and benzo $[g, h, i]$ perylene (BghiP).

\subsection{PAH quality control}

All analytical procedures were monitored using strict quality control measures. Decafluorobiphenyl $(99.99 \%)$ was spiked into each water sample before extraction, to monitor the efficiency of the extraction and cleanup procedures; its recoveries were $61 \%$ $-110 \%$. In addition, a method blank (solvent), a spiked blank (standards spiked into solvent), and duplicate samples were analyzed. The average spiked PAH recovery was $62 \%-107 \%$. The differences between individual PAH congener concentrations in the duplicate samples were all $<16 \%$.

\subsection{PAH source identification}

Identifying the possible PAH sources and their relative contributions in run-off is critical for understanding and controlling PAH pollution in aquatic environments. Several useful methods have been developed to identify PAH sources and estimate their relative contributions, such as positive matrix factorization (PMF), principal component analysismultiple linear regression (PCA-MLR) and unmix (Larsen and Baker, 2003; Junninen et al., 2009; Yang et al., 2013). Compared with other models, PMF imposes non-negativity constraints on both the source profiles and the resulting contributions, and allows for proper variable scaling (Sofowote et al., 2008; Ma et al., 2010). Due to the relatively small number of samples and large variation of PAHs in samples, we used PMF to identify the PAH sources and their relative contributions to impervious surface run-off in the Shanghai urban area.

Detailed descriptions of PMF can be found in 
previous studies (Norris et al., 2008; Sofowote et al., 2008). In this study, the EPA PMF 3.0 (Norris et al., 2008) was used.

\section{Results and discussion}

\subsection{PAH concentrations}

Fig. 3 shows the mean concentrations of the $\sum 16$ PAHs (the sum of the sixteen PAHs analyzed) and the $\sum 7$ PAHs (the sum of seven carcinogenic PAHs, BaA, $\mathrm{BaP}, \mathrm{BbF}, \mathrm{BkF}$, Chy, DBahA, and IP) in the three impervious surface run-off samples and the rainwater. The mean $\sum 16 \mathrm{PAH}$ concentrations in the rainwater, ceramic tile roof run-off, asphalt roof run-off, and asphalt road run-off samples were 873, 1404, 1743, and $4023 \mathrm{ng} / \mathrm{L}$, respectively. The mean $\sum 16 \mathrm{PAH}$ concentration ratios between rainwater and ceramic tile roof run-off and between rainwater and asphalt roof run-off were $62.2 \%$ and $50.1 \%$, respectively,

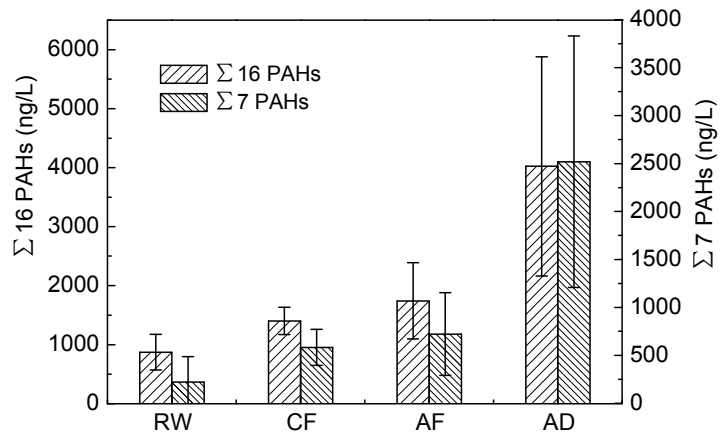

Fig. 3 Mean PAH concentrations in the samples analyzed $\mathrm{RW}$ : rainwater, $\mathrm{CF}$ : ceramic tile roof run-off, $\mathrm{AF}$ : asphalt roof run-off, $\mathrm{AD}$ : asphalt road run-off implying that wet deposition was a primary source of PAHs in roof run-off. The mean $\sum 16$ PAH concentration was higher in $\mathrm{AF}$ than in $\mathrm{CF}$, possibly because PAHs were leached from the asphalt roofing materials at the AF site because of high temperatures caused by exposure to the sun. The PAH sources in road run-off are complicated, and include vehicle exhausts, emissions caused by tire friction, and road aging. The PAH concentrations were much higher in the road run-off than in the roof run-off. The mean $\Sigma 7$ PAH concentration at $\mathrm{AD}$ was $2517 \mathrm{ng} / \mathrm{L}$, which could constitute a great threat to the environment and humans. The mean $\sum 7 \mathrm{PAH}$ concentrations in the run-off from the two types of roof were not considered to be a significant threat to the environment and humans.

The PAH concentrations in the surface run-off found in this study and in other studies around the world are shown in Table 2. The PAH concentrations found in the run-off from the asphalt road surface in Shanghai were similar to that found in other areas. The PAH concentrations in this study in the run-off from a ceramic tile roof in Shanghai were lower than that found in Beijing, and the PAH concentrations in asphalt roof run-off were lower in Shanghai than in Nanjing. The PAH concentrations were higher in asphalt roof run-off than in run-off from roofs made of other materials. In summary, the PAH concentrations in impervious surface run-off in the Shanghai urban area were moderate compared to concentrations found elsewhere.

\subsection{PAH composition characteristics}

Concentrations of the individual PAHs in the RW and run-off samples were calculated (Table 3).

Table 2 PAH concentrations in surface run-offs in different regions

\begin{tabular}{llll}
\hline \multicolumn{1}{c}{ Location } & PAHs & Concentration $(\mathrm{ng} / \mathrm{L})$ & \multicolumn{1}{c}{ Reference } \\
\hline Asphalt road, Shanghai, China & $\sum 16$ & 4023 & This study \\
Urban road, Beijing, China & $\sum 16$ & $500-38900$ & Zhang et al., 2008 \\
Highway, Netherlands & $\sum 16$ & $5200-5800$ & Berbee et al., 1999 \\
Highway, USA & $\sum 14$ & $400-16300$ & Ngabe et al., 2000 \\
Ceramic tile roof, Shanghai, China & $\sum 16$ & 1404 & This study \\
Asphalt roof, Shanghai, China & $\sum 16$ & 1743 & This study \\
Asphalt roof, Nanjing, China & $\sum 15$ & 4261.7 & Zhang et al., 2012 \\
Tile roof, Nanjing, China & $\sum 15$ & 351.2 & Zhang et al., 2012 \\
Ceramic tile roof, Beijing, China & $\sum 16$ & 2320 & Hu et al., 2010 \\
Zinc roof, Poland & $\sum 6$ & 232.6 & Tsakovski et al., 2010 \\
Ceramic tile roof, Poland & $\sum 6$ & 197 & Tsakovski et al., 2010 \\
\hline
\end{tabular}


The PAHs found at the highest concentrations in the RW were $\mathrm{An}, \mathrm{Fl}, \mathrm{NaP}$, and $\mathrm{PhA}$, and the low molecular weight PAHs were, generally, the dominant components. This suggested that the low molecular weight PAHs were mostly present in the gaseous phase because of their high vapor pressures. The dominant PAHs in the CF samples were An, BaA, FlA, and Py, and the dominant PAHs in the AF samples were An, BaA, Chy, FlA, PhA, and Py (i.e., similar to the dominant PAHs in the CF samples but at higher concentrations). The high molecular weight PAHs dominated the AD samples, with IP, FlA, and BaA being found at the highest concentrations (in descending order). In some studies, FlA, PhA, and Py have been found to be the main PAHs that threaten aquatic ecological systems (Boxall and Maltby, 1997). These three PAHs were found at relatively high concentrations in our study, suggesting that impervious surface run-off is a potential threat to local ecological systems, and should be discharged only after being treated properly.

As shown in Table 4, the 16 PAHs can be divided into five groups, containing 2-, 3-, 4-, 5-, and 6-ring PAHs, according to the number of benzene rings in the molecule. RW was dominated by 3-ring PAHs and the roof run-off samples ( $\mathrm{CF}$ and $\mathrm{AF}$ ) were dominated by 3-4-ring PAHs, accounting for more than $50 \%$ of the total PAHs. The major components of the AD samples were 4-6-ring PAHs. The PAH compositions of the roof run-off samples were similar to the RW sample compositions, further proving that wet deposition was an important source of PAHs in roof run-off. PAHs in the road run-off were less affected by wet deposition.

\subsection{PAH source identification using positive ma- trix factorization}

Three $16 \times 7$ (16 PAHs and 7 samples) datasets were used in the EPA PMF 3.0 model, to estimate the source contributions to the $\sum \mathrm{PAH}$ concentrations in the impervious surface run-off. For each dataset, the number of factors and $Q$ values were tested to obtain

Table 4 Distributions (\%) of PAHs (grouped by the number of rings) in the samples

\begin{tabular}{cccccc}
\hline \multirow{2}{*}{ Sample } & \multicolumn{5}{c}{ Distribution of PAHs (\%) } \\
\cline { 2 - 6 } & 2-ring & 3-ring & 4-ring & 5-ring & 6-ring \\
\hline RW & 12.0 & 50.9 & 23.3 & 11.2 & 2.5 \\
CF & 6.7 & 29.3 & 28.2 & 22.7 & 13.1 \\
AF & 3.6 & 30.2 & 32.3 & 21.6 & 12.3 \\
AD & 3.0 & 14.7 & 34.4 & 23.4 & 24.5 \\
\hline
\end{tabular}

RW: rainwater, $\mathrm{CF}$ : ceramic tile roof run-off, $\mathrm{AF}$ : asphalt roof run-off, $\mathrm{AD}$ : asphalt road run-off)

Table 3 Concentrations of the individual PAHs in the samples $(\mathrm{ng} / \mathrm{L})(n=7)$

\begin{tabular}{|c|c|c|c|c|}
\hline \multirow{2}{*}{$\mathrm{PAH}^{*}$} & \multicolumn{4}{|c|}{ Concentration (ng/L) } \\
\hline & RW & $\mathrm{CF}$ & $\mathrm{AF}$ & $\mathrm{AD}$ \\
\hline $\mathrm{NaP}$ & $97 \pm 27(66-128)$ & $95 \pm 23(63-129)$ & $65 \pm 42(5-112)$ & $92 \pm 26(67-137)$ \\
\hline $\mathrm{AcNy}$ & n.d. & $77 \pm 38$ (n.d.-108) & $51 \pm 48$ (n.d. -112$)$ & $24 \pm 45$ (n.d. -115$)$ \\
\hline F1 & $85 \pm 39$ (n.d. -116$)$ & $68 \pm 42$ (n.d. -114$)$ & $87 \pm 71(23-232)$ & $91 \pm 34(32-137)$ \\
\hline $\mathrm{AcNe}$ & $81 \pm 56$ (n.d. -130$)$ & $74 \pm 56$ (n.d. -136$)$ & $101 \pm 45(8-155)$ & $114 \pm 27(86-157)$ \\
\hline $\mathrm{PhA}$ & $103 \pm 30(51-141)$ & $47 \pm 37(14-125)$ & $143 \pm 93(11-241)$ & $154 \pm 128(22-369)$ \\
\hline An & $134 \pm 27(102-178)$ & $135 \pm 27(100-175)$ & $129 \pm 80(5-273)$ & $108 \pm 41(45-168)$ \\
\hline FlA & $71 \pm 39(30-138)$ & $108 \pm 63(8-202)$ & $193 \pm 131(19-352)$ & $567 \pm 395(155-1150)$ \\
\hline Py & $65 \pm 31(32-119)$ & $128 \pm 28(86-169)$ & $136 \pm 68(63-260)$ & $98 \pm 42(45-175)$ \\
\hline $\mathrm{BaA}$ & $34 \pm 39$ (n.d. -109$)$ & $113 \pm 37(54-161)$ & $119 \pm 78(19-259)$ & $524 \pm 416(10-1324)$ \\
\hline Chy & $39 \pm 28(6-90)$ & $49 \pm 31(12-98)$ & $116 \pm 142(4-402)$ & $336 \pm 361(34-890)$ \\
\hline $\mathrm{BbF}$ & $41 \pm 61$ (n.d. -158 ) & $88 \pm 31(49-149)$ & $82 \pm 82$ (n.d. -243 ) & $364 \pm 305(108-951)$ \\
\hline $\mathrm{BkF}$ & $42 \pm 59$ (n.d. -140$)$ & $110 \pm 33(69-166)$ & $107 \pm 72(37-260)$ & $264 \pm 247(6-545)$ \\
\hline $\mathrm{BaP}$ & $12 \pm 26$ (n.d. -69$)$ & $32 \pm 32(3-83)$ & $64 \pm 63(9-159)$ & $182 \pm 251(19-718)$ \\
\hline DBahA & $42 \pm 73$ (n.d. -168 ) & $93 \pm 27(54-130)$ & $133 \pm 75(11-258)$ & $121 \pm 79(30-264)$ \\
\hline BghiP & $16 \pm 43$ (n.d. -113 ) & $89 \pm 35(53-149)$ & $116 \pm 66(64-258)$ & $259 \pm 253(66-749)$ \\
\hline IP & $9 \pm 3(7-16)$ & $97 \pm 71(16-228)$ & $101 \pm 68(43-250)$ & $727 \pm 393(141-1351)$ \\
\hline
\end{tabular}

* PAH abbreviations were given in Section 1.3. Data were expressed as mean \pm SD (range); n.d.: not detected; RW: rainwater, CF: ceramic tile roof run-off, $\mathrm{AF}$ : asphalt roof run-off, $\mathrm{AD}$ : asphalt road run-off 
well-fitting results that could fully explain the raw data. Factor numbers ranging from 3 to 6 were tried in order to choose the "optimal solution". Fifty runs were made for each factor, and the convergent run with the minimum $Q_{\text {robust }}$ was used for the optimal solutions (Ma et al., 2010). The PMF model identified four factors for roof run-off and five factors for road run-off, as shown in Tables 5, 6, and 7.

\section{Ceramic tile roof run-off}

The first factor had high concentrations of the PAHs AcNy, An, Fl, and FlA, which are associated with coal combustion (Larsen and Baker, 2003; Bzdusek et al., 2004), so this factor represented coal combustion sources. The second factor was dominated by BbF, BghiP, BkF, DBahA, and IP. Of these, $\mathrm{BbF}, \mathrm{BghiP}$, and $\mathrm{BkF}$ are markers of gasoline sources (Larsen and Baker, 2003) and IP is a marker for diesel sources (Harrison et al., 1996; Li et al., 2006), so the second factor represented vehicular emission sources. The third factor was highly related to $\mathrm{BaA}$, which is an indicator of natural gas combustion (Simcik et al., 1999). The fourth factor had no significant markers, and was possibly associated with mixed sources, so it is referred to as 'others'.

\section{Asphalt roof run-off}

The first factor was dominated by BbF, BghiP, $\mathrm{BkF}$, DBahA, and IP, which are associated with vehicular emissions (Harrison et al., 1996; Larsen and Baker, 2003; Li et al., 2006). The second factor had high weightings for An, FlA, PhA, and Py, which are associated with coal combustion (Larsen and Baker, 2003; Bzdusek et al., 2004). The third factor was highly related to Chy, FlA, and Py. Chy is a marker of petroleum sources ( $\mathrm{Li}$ et al., 2006), indicating that this factor represented petroleum sources. The fourth factor was dominated by $\mathrm{BaA}$, which is a marker for natural gas combustion sources (Simcik et al., 1999).

\section{Asphalt road run-off}

The first factor represented gasoline emissions, based on its weightings for BaP, BghiP, and IP (Larsen and Baker, 2003). The second factor was highly weighted toward BaA, Chy, FlA, and IP. BaA is a marker for natural gas combustion and FlA is a marker for coal combustion (Larsen and Baker, 2003; Bzdusek et al., 2004), so the second factor was identified as representing combustion sources (Simcik et al., 1999). The third factor was identified as representing diesel emissions because it was strongly
Table 5 Source profiles for ceramic tile roof run-off obtained using positive matrix factorization

\begin{tabular}{ccccc}
\hline PAH $^{*}$ & Factor 1 & Factor 2 & Factor 3 & Factor 4 \\
\hline $\mathrm{NaP}$ & 0.062 & 0.072 & 0.065 & 0.098 \\
$\mathrm{AcNy}$ & 0.104 & 0.000 & 0.074 & 0.033 \\
$\mathrm{Fl}$ & 0.109 & 0.006 & 0.028 & 0.000 \\
$\mathrm{AcNe}$ & 0.000 & 0.000 & 0.093 & 0.182 \\
$\mathrm{PhA}$ & 0.001 & 0.049 & 0.031 & 0.058 \\
$\mathrm{An}$ & 0.117 & 0.110 & 0.004 & 0.038 \\
$\mathrm{FlA}$ & 0.136 & 0.034 & 0.000 & 0.160 \\
$\mathrm{Py}$ & 0.062 & 0.086 & 0.076 & 0.033 \\
$\mathrm{BaA}$ & 0.047 & 0.089 & 0.204 & 0.037 \\
$\mathrm{Chy}$ & 0.001 & 0.060 & 0.027 & 0.051 \\
$\mathrm{BbF}$ & 0.039 & 0.093 & 0.064 & 0.070 \\
$\mathrm{BkF}$ & 0.104 & 0.098 & 0.082 & 0.010 \\
$\mathrm{BaP}$ & 0.000 & 0.025 & 0.001 & 0.102 \\
$\mathrm{DBahA}$ & 0.096 & 0.086 & 0.098 & 0.118 \\
$\mathrm{BghiP}$ & 0.085 & 0.109 & 0.074 & 0.009 \\
$\mathrm{IP}$ & 0.037 & 0.082 & 0.079 & 0.000 \\
\hline Contribu & 33.8 & 30.5 & 21.7 & 14.1 \\
-tion (\%) & & & & \\
Source & Coal & Vehicular & Natural gas & Others \\
& combustion & emission & combustion & \\
\hline PAH & & &
\end{tabular}

* PAH abbreviations were given in Section 1.3

Table 6 Source profiles for asphalt roof run-off obtained using positive matrix factorization

\begin{tabular}{|c|c|c|c|c|}
\hline PAH $^{*}$ & Factor 1 & Factor 2 & Factor 3 & Factor 4 \\
\hline $\mathrm{NaP}$ & 0.008 & 0.036 & 0.000 & 0.116 \\
\hline $\mathrm{AcNy}$ & 0.001 & 0.076 & 0.011 & 0.000 \\
\hline Fl & 0.095 & 0.043 & 0.011 & 0.013 \\
\hline $\mathrm{AcNe}$ & 0.079 & 0.071 & 0.002 & 0.070 \\
\hline $\mathrm{PhA}$ & 0.000 & 0.111 & 0.131 & 0.137 \\
\hline An & 0.123 & 0.091 & 0.000 & 0.038 \\
\hline FlA & 0.000 & 0.161 & 0.152 & 0.179 \\
\hline Py & 0.059 & 0.098 & 0.115 & 0.027 \\
\hline $\mathrm{BaA}$ & 0.069 & 0.014 & 0.044 & 0.232 \\
\hline Chy & 0.042 & 0.012 & 0.238 & 0.028 \\
\hline $\mathrm{BbF}$ & 0.088 & 0.000 & 0.059 & 0.055 \\
\hline $\mathrm{BkF}$ & 0.102 & 0.054 & 0.040 & 0.010 \\
\hline $\mathrm{BaP}$ & 0.020 & 0.020 & 0.108 & 0.000 \\
\hline DBahA & 0.118 & 0.103 & 0.005 & 0.033 \\
\hline BghiP & 0.105 & 0.061 & 0.039 & 0.040 \\
\hline IP & 0.091 & 0.049 & 0.044 & 0.022 \\
\hline $\begin{array}{l}\text { Contribu } \\
\text {-tion (\%) }\end{array}$ & 33.0 & 32.7 & 19.6 & 14.7 \\
\hline Source & $\begin{array}{l}\text { Vehicular } \\
\text { emission }\end{array}$ & $\begin{array}{c}\text { Coal } \\
\text { combustion }\end{array}$ & Petroleum & $\begin{array}{l}\text { Natural gas } \\
\text { combustion }\end{array}$ \\
\hline
\end{tabular}

\footnotetext{
* PAH abbreviations were given in Section 1.3
} 
Table 7 Source profiles for asphalt road run-off obtained using positive matrix factorization

\begin{tabular}{cccccc}
\hline PAH $^{*}$ & Factor 1 & Factor 2 & Factor 3 & Factor 4 & Factor 5 \\
\hline $\mathrm{NaP}$ & 0.008 & 0.008 & 0.036 & 0.016 & 0.072 \\
$\mathrm{AcNy}$ & 0.000 & 0.000 & 0.000 & 0.003 & 0.001 \\
$\mathrm{Fl}$ & 0.013 & 0.004 & 0.042 & 0.000 & 0.081 \\
$\mathrm{AcNe}$ & 0.006 & 0.009 & 0.043 & 0.033 & 0.086 \\
$\mathrm{PhA}$ & 0.028 & 0.064 & 0.005 & 0.108 & 0.005 \\
$\mathrm{An}$ & 0.010 & 0.001 & 0.055 & 0.002 & 0.099 \\
$\mathrm{FlA}$ & 0.130 & 0.194 & 0.062 & 0.291 & 0.079 \\
$\mathrm{Py}$ & 0.004 & 0.003 & 0.062 & 0.018 & 0.049 \\
$\mathrm{BaA}$ & 0.088 & 0.237 & 0.112 & 0.129 & 0.023 \\
$\mathrm{Chy}$ & 0.136 & 0.059 & 0.000 & 0.257 & 0.000 \\
$\mathrm{BbF}$ & 0.040 & 0.096 & 0.051 & 0.023 & 0.077 \\
$\mathrm{BkF}$ & 0.004 & 0.242 & 0.001 & 0.000 & 0.093 \\
$\mathrm{BaP}$ & 0.161 & 0.004 & 0.022 & 0.007 & 0.033 \\
$\mathrm{DBahA}$ & 0.027 & 0.000 & 0.001 & 0.049 & 0.109 \\
$\mathrm{BghiP}$ & 0.181 & 0.028 & 0.034 & 0.000 & 0.077 \\
$\mathrm{IP}$ & 0.163 & 0.053 & 0.473 & 0.062 & 0.115 \\
\hline Contribu & 24.2 & 23.5 & 23.0 & 16.3 & 13.1 \\
-tion (\%) & \multicolumn{7}{c}{ Source } & Gasoline Combus & Diesel & Petroleum & Others \\
emission & - -tion & emission & & \\
\hline * & &
\end{tabular}

${ }^{*}$ PAH abbreviations were given in Section 1.3

weighted toward IP (Harrison et al., 1996; Li et al., 2006). The fourth factor was strongly related to Chy and FlA, which are indicators of petroleum sources. The fifth factor was dominated by An, BkF, DBahA, $\mathrm{Fl}$, and IP, and was possibly associated with mixed sources, referred to as 'others'.

4. Comparison of source contributions in different surface run-off samples

The estimated source contributions to the samples from each site were calculated in Table 8. To facilitate comparisons, coal and natural gas combustion were combined as 'combustion', and gasoline and diesel emissions were combined as 'vehicular emission'. As shown in Table 8, PAHs in the roof run-off samples mainly came from combustion $(47.4 \%-55.5 \%)$ and vehicular emissions $(30.5 \%-$ $33.0 \%)$. Petroleum was also a source $(19.6 \%)$ for asphalt roof run-off, possibly because of PAHs being leached from the asphalt roof material. Vehicular emissions were the most significant sources $(47.2 \%)$ for asphalt road run-off, followed by combustion $(23.5 \%)$, and petroleum $(16.3 \%)$. In summary, vehicular emissions and coal/natural gas combustion were the main PAH sources for impervious surface run-offs in urban Shanghai.

Table 8 Source contribution of PAHs in different impervious surface run-offs (\%)

\begin{tabular}{lccc}
\hline \multicolumn{1}{c}{ Source } & CF & AF & AD \\
\hline Combustion & 55.5 & 47.4 & 23.5 \\
Vehicular emission & 30.5 & 33.0 & 47.2 \\
Petroleum & & 19.6 & 16.3 \\
Others & 14.1 & & 13.1 \\
\hline $\begin{array}{l}\text { CF: ceramic tile roof run-off, AF: asphalt roof run-off, AD: asphalt } \\
\text { road run-off }\end{array}$
\end{tabular}

Coal is the main energy source in Shanghai and accounts for almost $32 \%$ of Shanghai's total energy consumption in 2011 (Shanghai Municipal Statistics Bureau, 2012) and explains the high contribution of coal combustion to the PAHs found in the run-off samples. The number of private cars in Shanghai has risen sharply in the last few years, causing heavy traffic and significant traffic pollution, especially in urban areas. Vehicular emissions have, therefore, become an important source of pollution in the urban environment in Shanghai. Natural gas is the primary residential energy source in Shanghai. The study area is a combined residential area, so natural gas combustion is a primary source of PAHs in run-off in the area. In summary, energy consumption is the dominant factor affecting the PAHs in the run-off from impervious surfaces in the Shanghai urban area.

\section{Conclusions}

The characteristics and sources of 16 priority PAHs were studied in run-off from three types of impervious surfaces and in rainwater in an urban area of Shanghai, China. The mean $\sum 16$ PAH concentrations in the rainwater, ceramic tile roof run-off, asphalt roof run-off, and asphalt road run-off were 873 , 1404, 1743, and $4023 \mathrm{ng} / \mathrm{L}$, respectively. The PAH concentrations found in the run-off in this study were moderate compared with concentrations found in other studies. The rainwater samples were dominated by 3-ring PAHs, whereas 3-4-ring PAHs dominated the roof run-off samples, and 4-6-ring PAHs were dominant in the road run-off samples. Positive matrix factorization suggested that vehicular emissions and coal and gas combustion were the main sources of 
PAHs in the run-off samples. These results will be of use in identifying appropriate measures for controlling PAH pollution in stormwater run-off and improving environmental quality in the Shanghai urban area.

\section{References}

Bartlett, A.J., Rochfort, Q., Brown, L.R., Marsalek, J., 2012. Causes of toxicity to Hyalella azteca in a stormwater management facility receiving highway runoff and snowmelt. Part I: Polycyclic aromatic hydrocarbons and metals. Science of the Total Environment, 414:227-237. [doi:10.1016/j.scitotenv.2011.11.041]

Berbee, R., Rijs, G., de Brouwer, R., van Velzen, L., 1999. Characterization and treatment of runoff from highways in the Netherlands paved with impervious and pervious asphalt. Water Environment Research, 71(2):183-190. [doi:10.2175/106143098X121914].

Boxall, A., Maltby, L., 1997. The effects of motorway runoff on freshwater ecosystems: 3. Toxicant confirmation. $A r$ chives of Environmental Contamination and Toxicology, 33(1):9-16. [doi:10.1007/s002449900216]

Bzdusek, P.A., Christensen, E.R., Li, A., Zou, Q., 2004. Source apportionment of sediment PAHs in Lake Calumet, Chicago: Application of factor analysis with nonnegative constraints. Environmental Science \& Technology, 38(1): 97-103. [doi:10.1021/es034842k]

Chang, M., McBroom, M.W., Scott Beasley, R., 2004. Roofing as a source of nonpoint water pollution. Journal of Environmental Management, 73(4):307-315. [doi:10. 1016/j.jenvman.2004.06.014]

Diblasi, C.J., Li, H., Davis, A.P., Ghosh, U., 2009. Removal and fate of polycyclic aromatic hydrocarbon pollutants in an urban stormwater bioretention facility. Environmental Science \& Technology, 43(2):494-502. [doi:10.1021/ es802090g]

Grynkiewicz, M., Polkowska, Ż., Namieśnik, J., 2002. Determination of polycyclic aromatic hydrocarbons in bulk precipitation and runoff waters in an urban region (Poland). Atmospheric Environment, 36(2):361-369. [doi:10. 1016/S1352-2310(01)00266-7]

Harrison, R.M., Smith, D., Luhana, L., 1996. Source apportionment of atmospheric polycyclic aromatic hydrocarbons collected from an urban location in Birmingham, UK. Environmental Science \& Technology, 30(3):825832. [doi:10.1021/es950252d]

Hu, D., Ou, L.B., Huang, H., Cui, S.Y., Guo, T.J., Zhang, W., Wang, X.J., 2010. Concentration characteristics and source identification of PAHs in urban roof runoff in Beijing. Ecology and Environmental Sciences, 19(11): 2613-2618 (in Chinese).

Junninen, H., Monster, J., Rey, M., Cancelinha, J., Douglas, K., Duane, M., Forcina, V., Muller, A., Lagler, F., Marelli, L., et al., 2009. Quantifying the impact of residential heating on the urban air quality in a typical European coal combustion region. Environmental Science \& Technology,
43(20):7964-7970. [doi:10.1021/es8032082]

Kafi, M., Gasperi, J., Moilleron, R., Gromaire, M.C., Chebbo, G., 2008. Spatial variability of the characteristics of combined wet weather pollutant loads in Paris. Water Research, 42(3):539-549. [doi:10.1016/j.watres.2007.08. 008]

Krein, A., Schorer, M., 2000. Road runoff pollution by polycyclic aromatic hydrocarbons and its contribution to river sediments. Water Research, 34(16):4110-4115. [doi:10. 1016/S0043-1354(00)00156-1]

Larsen, R.K., Baker, J.E., 2003. Source apportionment of polycyclic aromatic hydrocarbons in the urban atmosphere: A comparison of three methods. Environmental Science \& Technology, 37(9):1873-1881. [doi:10.1021/ es0206184]

Lau, S.L., Han, Y., Kang, J.H., Kayhanian, M., Stenstrom, M.K., 2009. Characteristics of highway stormwater runoff in Los Angeles: metals and polycyclic aromatic hydrocarbons. Water Environment Research, 81(3):308318. [doi:10.2175/106143008X357237]

Li, J., Zhang, G., Li, X.D., Qi, S.H., Liu, G.Q., Peng, X.Z., 2006. Source seasonality of polycyclic aromatic hydrocarbons (PAHs) in a subtropical city, Guangzhou, South China. Science of the Total Environment, 355(1-3): 145-155. [doi:10.1016/j.scitotenv.2005.02.042]

Liang, J., Ma, G.J., Fang, H.L., Chen, L., Christie, P., 2011. Polycyclic aromatic hydrocarbon concentrations in urban soils representing different land use categories in Shanghai. Environmental Earth Sciences, 62(1):33-42. [doi:10.1007/s12665-010-0493-7]

Liu, Y., Chen, L., Zhao, J.F., Huang, Q.H., Zhu, Z.L., Gao, H.W., 2008. Distribution and sources of polycyclic aromatic hydrocarbons in surface sediments of rivers and an estuary in Shanghai, China. Environmental Pollution, 154(2):298-305. [doi:10.1016/j.envpol.2007.10.020]

Ma, W.L., Li, Y.F., Qi, H., Sun, D.Z., Liu, L.Y., Wang, D.G., 2010. Seasonal variations of sources of polycyclic aromatic hydrocarbons (PAHs) to a northeastern urban city, China. Chemosphere, 79(4):441-447. [doi:10.1016/j. chemosphere.2010.01.048]

Mitsova, D., Vos, J., Gardinali, P., Stafeychuk, I., 2011. Variability in road runoff pollution by polycyclic aromatic hydrocarbons (PAHs) in the urbanized area adjacent to Biscayne Bay, Florida. Journal of Environmental Protection, 2(10):1317-1330. [doi:10.4236/jep.2011.210152]

Ngabe, B., Bidleman, T.F., Scott, G.I., 2000. Polycyclic aromatic hydrocarbons in storm runoff from urban and coastal South Carolina. Science of the Total Environment, 255(1-3):1-9. [doi:10.1016/S0048-9697(00)00422-8]

Norris, G., Vedantham, R., Wade, K., Brown, S., Prouty, J., Foley, C., 2008. EPA Positive Matrix Factorization (PMF) 3.0 Fundamentals \& User Guide. Prepared for the US Environmental Protection Agency, Washington, DC, by the National Exposure Research Laboratory, Research Triangle Park.

Shanghai Municipal Statistics Bureau, 2012. Shanghai Statistical Year Book. Beijing, China, p.80 (in Chinese). 
Simcik, M.F., Eisenreich, S.J., Lioy, P.J., 1999. Source apportionment and source/sink relationships of PAHs in the coastal atmosphere of Chicago and Lake Michigan. Atmospheric Environment, 33(30):5071-5079. [doi:10. 1016/S1352-2310(99)00233-2]

Sofowote, U.M., McCarry, B.E., Marvin, C.H., 2008. Source apportionment of PAH in Hamilton Harbour suspended sediments: comparison of two factor analysis methods. Environmental Science \& Technology, 42(16):6007-6014. [doi:10.1021/es800219z]

Tsakovski, S., Tobiszewski, M., Simeonov, V., Polkowska, Ż., Namieśnik, J., 2010. Chemical composition of water from roofs in Gdansk, Poland. Environmental Pollution, 158(1):84-91. [doi:10.1016/j.envpol.2009.07.037]

Valle, S., Panero, M.A., Shor, L., 2007. Pollution Prevention and Management Strategies for Polycyclic Aromatic Hydrocarbons in the New York/New Jersey Harbor. New York Academy of Sciences, New York.

Yan, L., Li, X., Chen, J., Wang, X., Du, J., Ma, L., 2012.
Source and deposition of polycyclic aromatic hydrocarbons to Shanghai, China. Journal of Environmental Sciences, 24(1):116-123. [doi:10.1016/S1001-0742(10) 60638-9]

Yang, B., Zhou, L., Xue, N., Li, F., Li, Y., Vogt, R.D., Cong, X., Yan, Y., Liu, B., 2013. Source apportionment of polycyclic aromatic hydrocarbons in soils of Huanghuai Plain, China: Comparison of three receptor models. Science of the Total Environment, 443:31-39. [doi:10.1016/ j.scitotenv.2012.10.094]

Zhang, W., Zhang, S., Yue, D., Wan, C., Ye, Y., Wang, X., 2008. Characterization and loading estimation of polycyclic aromatic hydrocarbons in road runoff from urban regions of Beijing, China. Environmental Toxicology and Chemistry, 27(1):31-37. [doi:10.1897/07-030.1]

Zhang, K.F., Fu, D.F., Li, H., 2012. Comparison and analysis characteristic of PAHs pollution for different types of roof runoff. Journal of Southeast University (Natural Science Edition), 42(1):99-103 (in Chinese). 